\title{
Physiological Responses of Rosa rubiginosa to Saline Environment
}

\author{
Tomasz Hura • Bożena Szewczyk-Taranek • \\ Katarzyna Hura • Krzysztof Nowak • \\ Bożena Pawłowska
}

Received: 4 October 2016 / Accepted: 17 January 2017 /Published online: 28 January 2017

(C) The Author(s) 2017. This article is published with open access at Springerlink.com

\begin{abstract}
The aim of this work was to analyse the response of Rosa rubiginosa to salinity induced by different concentrations of sodium chloride and calcium chloride $(0,25,50,100,150$ and $200 \mathrm{mM})$. Besides salt accumulation and $\mathrm{pH}$ changes, other parameters were investigated including photosynthetic activity, leaf water content, the dynamics of necrosis and chlorosis appearance and leaf drying. The study was complemented with microscopic analysis of changes in leaf anatomy. $R$. rubiginosa was more sensitive to the salinity induced by calcium chloride than by sodium chloride. Plant response to salinity differed depending of the salt concentration. These differences were manifested by higher dynamics of necrosis and
\end{abstract}

Electronic supplementary material The online version of this article (doi:10.1007/s11270-017-3263-2) contains supplementary material, which is available to authorized users.

\section{T. Hura $(\triangle)$}

Polish Academy of Sciences, The Franciszek Górski Institute of Plant Physiology, Niezapominajek 21, 30-239 Kraków, Poland e-mail: t.hura@ifr-pan.edu.pl

B. Szewczyk-Taranek · B. Pawłowska

Department of Ornamental Plants, Faculty of Biotechnology and Horticulture, University of Agriculture in Kraków, Al. 29

Listopada 54, 31-425 Kraków, Poland

\section{K. Hura}

Department of Plant Physiology, Faculty of Agriculture and Economics, University of Agriculture in Kraków, Podłużna 3, 30-239 Kraków, Poland

K. Nowak

Department of Dendrology and Landscape Architecture, Faculty of Biotechnology and Horticulture, University of Agriculture in Kraków, Al. 29 Listopada 54, 31-425 Kraków, Poland chlorosis appearance and leaf drying. $\mathrm{CaCl}_{2}$ showed greater inhibition of the photosynthetic apparatus and photosynthetic activity. Treatment with $\mathrm{CaCl}_{2}$ caused more visible deformation of palisade cells, reduction in their density and overall reduction in leaf thickness. The study demonstrated higher accumulation of $\mathrm{CaCl}_{2}$ in the soil, and thus greater limitations in water availability resulting in reduced leaf water content and quicker drying of leaves as compared with $\mathrm{NaCl}$-treated plants.

Keywords Salinity $\cdot$ Chlorosis $\cdot$ Chlorophyll fluorescence $\cdot$ Photosynthesis $\cdot$ Leaf anatomy

\section{Introduction}

Rosa rubiginosa is native to the entire area of Europe (Zimmermann et al. 2010, 2011). It is a fast growing shrub of bushy and branching habit (Fig. 1). It prefers sunny spots but grows well in slightly semi-shaded places. The species is tolerant of soil drought, urban contaminants, poor soils, frost and diseases (Kissell et al. 1987; Monder 2004a, b, 2012; Ritz et al. 2005; Sage et al. 2009; Svriz et al. 2013). Its resistance to adverse environmental conditions makes $R$. rubiginosa widely useful in urban green areas of natural character and in reclamation of polluted urban soils (De Pietri 1992; Sheley et al. 1996).

Many years of anthropogenic activity in urban areas caused considerable changes in the morphological, biological, physical and chemical properties of urban soils and destruction of their structure and nature (Pouyat et al. 1995). The soils of green strips surrounding urban 
communication routes contain also high concentration of salt $\left(\mathrm{NaCl}, \mathrm{CaCl}_{2}\right)$ as a consequence of using chemicals to make the roads less slippery (Cunningham et al. 2008; Novotny and Stefan 2010; Zeng et al. 2012). Chemical agents react with ice and water which do not freeze (the freezing point of water is reduced by the salt). Then, chlorides from melting snow get into the soil changing its chemical composition. A common effect of this approach is the death of roadside trees and shrubs due to physiological drought or disturbances in nutrient absorption (Czerniawska-Kusza et al. 2004; Di Tommaso 2004).

Considering its high effectiveness in soil reclamation, resistance to environmental stresses and positive influence on other plants, $R$. rubiginosa seems a useful species to be planted on salt-contaminated urban soils along the communication routes (Williams 1997).

The rate of metabolic disturbances and adaptability processes under salt stress differ depending on halophytic or glycophytic properties of species (Bankaji et al. 2016; Bowman et al. 2006; El-Haddad and Noaman 2001; Han et al. 2012; Redondo-Gómez et al. 2009). In the soils containing high concentrations of salt, water absorption by plant roots is limited (Zhang et al. 2016). This results in physiological drought manifested by a decrease in cell water content, stomatal closure and reduced photosynthetic performance (Nandy et al. 2007; Zhang et al. 2010). Therefore, an assessment of salt stress effects on the activity of photosynthetic apparatus in $R$. rubiginosa may be crucial to determine the level of salt tolerance of this species.

The aim of this study was to evaluate $R$. rubiginosa response to the salinity caused by sodium chloride and calcium chloride. $R$. rubiginosa may be a natural indicator of salt contamination in the soils surrounding the urban roads, and its presence may facilitate the assessment of an ecological status of such areas and their vegetation. Our research hypothesis assumed that variable salt concentrations would induce different response of $R$. rubiginosa. We analysed the activity of its photosynthetic apparatus, dynamics of necrosis and chlorosis appearance and drying of the leaves. The study was complemented by microscopic analysis of changes in the leaf anatomical structure.

\section{Materials and Methods}

\subsection{Plant Material, Growth Conditions and Treatments}

The current study was performed in young $R$. rubiginosa plants. The seeds used in the experiment (Fig. 1f) were collected at the turn of October and November from a shrub growing in natural conditions in the southern Poland (Fig. 1a). They were sown following a standard warm and cold stratification, 10 weeks at $25{ }^{\circ} \mathrm{C}$ and 13 weeks at $3{ }^{\circ} \mathrm{C}$. The seedlings were grown in a greenhouse (at day/night temperature of $25 / 20^{\circ} \mathrm{C} \pm 2{ }^{\circ} \mathrm{C}$; photosynthetic photon flux density, PPFD, from 150 to $200 \mu \mathrm{mol}$ (photons) $\mathrm{m}^{-2} \mathrm{~s}^{-1}$ ), in $9 \mathrm{~cm}$ diameter pots filled with Klasmann-Deilmann TS1 substrate. During growth and before flowering, the plants were chemically protected against powdery mildew and downy mildew. The experimental plants were cut at $15-20 \mathrm{~cm}$ and each of them had about 14 healthy leaves.

They were treated with $\mathrm{NaCl}$ and $\mathrm{CaCl}_{2}$ solutions at 0 (control), 25, 50, 100, 150 and $200 \mathrm{mM}$. The plants were treated with salt solutions for 32 days. $\mathrm{pH}$ of the substrate prior to the experiment was 6.8 , and electrical conductivity (EC) of the soil solution was about $300 \mu \mathrm{S}$ (Elmetron CPC-401, Zabrze, Poland). EC and pH of the substrate were analysed after 14 and 32 days of salt treatments. EC and $\mathrm{pH}$ values are average of three replicates.

\subsection{Measurements and Analyses}

During the experiment, the processes of necrosis, chlorosis and leaf drying were observed, and leaves showing evident these visible symptoms were counted on plant and expressed as percentage of control. Assessments of necrosis, chlorosis and leaf drying were taken in three replicates. A replication in an experiment represents a single plant (e.g. three replicates means three plants).

Leaf photosynthetic activity was assessed with Plant Vital R 5030 device (INNO-Concept GmbH, Germany). The molecular oxygen released from leaf surface of $R$. rubiginosa during photosynthesis under red light $(\lambda=630-650 \mathrm{~nm})$ was measured directly by means of Clark electrode. The Clark-type electrode enables to detect trace amounts of oxygen produced by PSII. The measurement temperature was maintained at a constant level. Photosynthetic activity was defined based on the amount of oxygen released from specific leaf area $\left(1 \mathrm{~m}^{2}\right)$ within specific time $(1 \mathrm{~min})$. The following measurable parameters were estimated: $R(\mathrm{mg} / \mathrm{l} \cdot \mathrm{s})$ oxygen evolving activity rate during the dark phase and $S(\mathrm{mg} / \mathrm{l} \cdot \mathrm{s})$ - oxygen evolving activity rate during the light phase between the minimum and maximum points. These two parameters were used to calculate the photosynthetic activity coefficient $K_{\mathrm{phA}}=-S / R$. The measurements were taken in five replicates. 
Fig. 1 R. rubiginosa in its natural environment in the southern Poland (Małopolska, near Kraków) (a), leaves (b); flower (c); shoot with prickles (d); fruit (e); seeds (f)

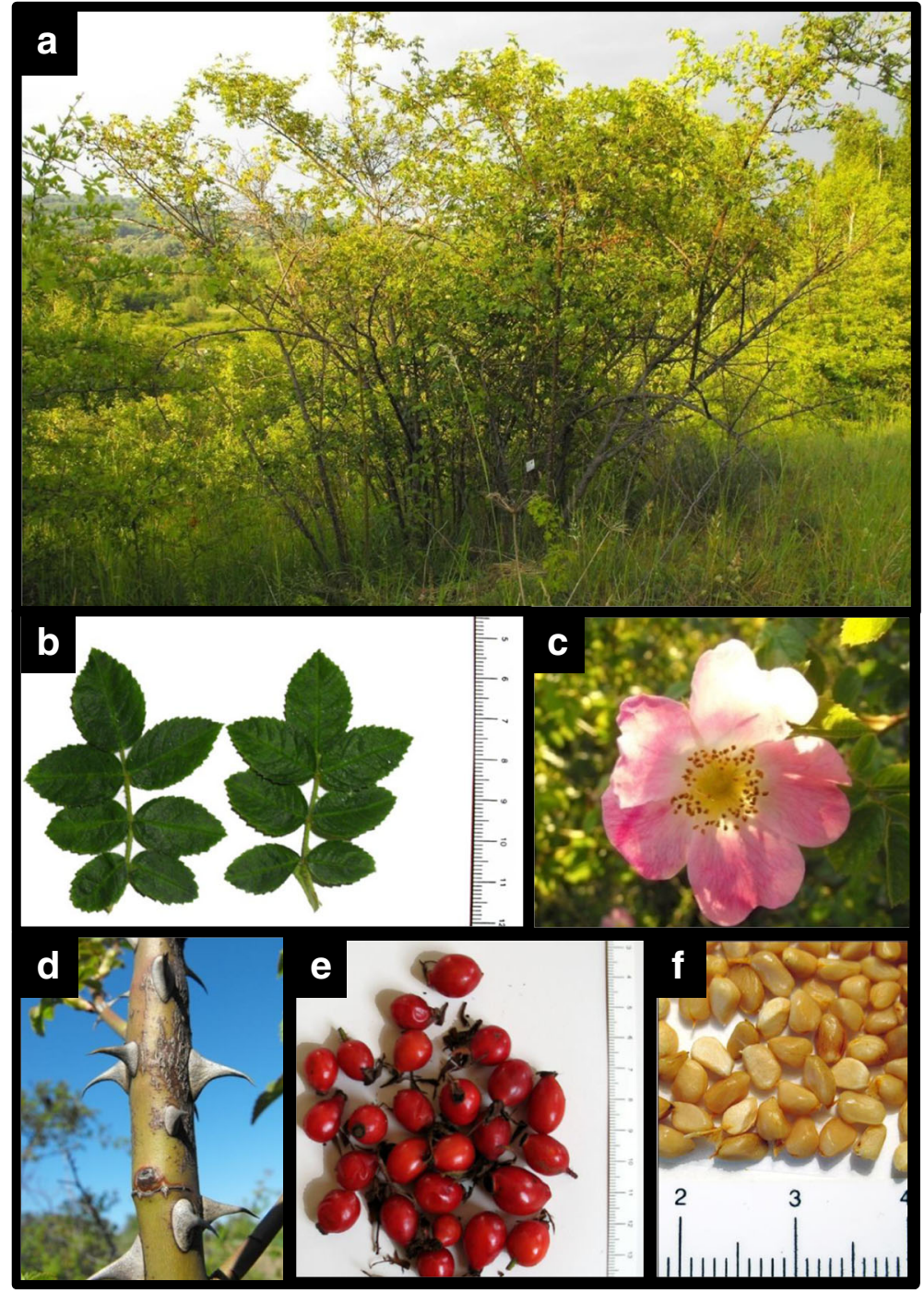

Chlorophyll fluorescence was measured with a fluorometer Mini-PAM (Walz, Effeltrich, Germany). To estimate maximum photochemical efficiency $\left(F_{\mathrm{v}} / F_{\mathrm{m}}\right)$, the leaves were adapted to darkness for $20 \mathrm{~min} . F_{\mathrm{v}} / F_{\mathrm{m}}$ was calculated according to van Kooten and Snel (1990) as $\left(F_{\mathrm{m}}-F_{0}\right) / F_{\mathrm{m}}$, where $F_{0}$ and $F_{\mathrm{m}}$ represented the minimum and maximum chlorophyll fluorescence, respectively. The minimum fluorescence was determined by switching on the modulated red light $(600 \mathrm{~nm})$. The maximum fluorescence with all PSII reaction centres closed was determined by a $0.7 \mathrm{~s}$ saturating pulse at $8000 \mu \mathrm{mol} \mathrm{m}{ }^{-2} \mathrm{~s}^{-1}$ in dark-adapted leaves. The measurements were taken in five replicates.

Leaf water content (LWC) and leaf dry weight (LDW) were measured by quantitative sampling of leaf fresh weight $\left(L_{\mathrm{FW}}\right)$, followed by drying at $80{ }^{\circ} \mathrm{C}$ for $24 \mathrm{~h}$. The resulting leaf dry weight $\left(L_{\mathrm{DW}}\right)$ was assessed and water content was calculated according to the following equation and expressed as a percentage: $\mathrm{LWC}=\left(\left(L_{\mathrm{FW}}-L_{\mathrm{DW}}\right) / L_{\mathrm{FW}}\right) \cdot 100 \%$. The measurements for LWC and LDW were taken in seven replicates.

Leaf anatomy was observed and photographed using a light microscope Jenaval (Carl Zeiss, Jena, Germany). A terminal leaflet of a compound leaf was harvested on the 12th day of the experiment. The plant material was fixed in glutaraldehyde (Sigma-Aldrich) (Forssmann 1969) and rinsed in 0.1 M phosphate buffer. Then, the leaf samples were dehydrated in ethanol and acetone and embedded in Epon 812 (Sigma-Aldrich) (Luft 1961). Resin blocks were cut with Tesla 490A 
ultramicrotome (Brno, Czech Republic). One micrometre thick sections were stained with Azure II (Sigma-Aldrich) and toluidine blue (Sigma-Aldrich) (Richardson et al. 1960).

\section{Results}

\section{$3.1 \mathrm{pH}$ and Soil Salinity}

Table 1 presents changes in soil $\mathrm{pH}$ and salinity depending on the concentration of $\mathrm{NaCl}$ and $\mathrm{CaCl}_{2}$ solutions used for watering of $R$. rubiginosa. After 14 days of treating with sodium chloride, the soil $\mathrm{pH}$ was neutral ( $\mathrm{pH}=7.0)$ or slightly alkaline $(\mathrm{pH}=7.1-7.3)$ and after 32 days it was either slightly alkaline $(\mathrm{pH}=7.0)$ or slightly acidic $(\mathrm{pH}=6.7-6.9)$. The soil treated with $\mathrm{CaCl}_{2}$ was slightly acidic after both $14(\mathrm{pH}=6.3-6.6)$ and 32 days $(\mathrm{pH}=6.1-6.4)$ (except for $0 \mathrm{mM}$ variant).

Conductometric measurements of soil salinity showed higher salt content for specific concentrations (except for $25 \mathrm{mM}$ after 14 days) in $\mathrm{CaCl}_{2}$ variant than in $\mathrm{NaCl}$ one. After 14 days, the salt content for the highest concentration of $200 \mathrm{mM}$ was about two times higher for $\mathrm{CaCl}_{2}$ than for $\mathrm{NaCl}$.

Table $1 \mathrm{pH}$ and electrical conductivity (EC) of the soil after 14 and 32 days of treating $R$. rubiginosa with $\mathrm{NaCl}$ and $\mathrm{CaCl}_{2}$ of different concentrations $(0,25,50,100,150,200 \mathrm{mM})$. Mean value $(n=3) \pm \mathrm{SE}$

\begin{tabular}{|c|c|c|c|c|}
\hline & \multicolumn{2}{|l|}{$\mathrm{pH}$} & \multicolumn{2}{|l|}{$\mathrm{EC}[\mathrm{mS}]$} \\
\hline & 14 days & 32 days & 14 days & 32 days \\
\hline \multicolumn{5}{|c|}{$\mathrm{NaCl}(\mathrm{mM})$} \\
\hline 0 & $6.8 \pm 0.13$ & $7.1 \pm 0.08$ & $0.3 \pm 0.08$ & $0.4 \pm 0.06$ \\
\hline 25 & $7.3 \pm 0.10$ & $7.1 \pm 0.09$ & $1.4 \pm 0.32$ & $3.7 \pm 0.63$ \\
\hline 50 & $7.1 \pm 0.05$ & $6.9 \pm 0.06$ & $2.8 \pm 0.20$ & $7.7 \pm 0.68$ \\
\hline 100 & $7.0 \pm 0.06$ & $6.7 \pm 0.07$ & $6.0 \pm 0.07$ & $12.5 \pm 0.65$ \\
\hline 150 & $7.2 \pm 0.09$ & $6.9 \pm 0.06$ & $6.4 \pm 0.20$ & $16.4 \pm 0.54$ \\
\hline 200 & $7.3 \pm 0.04$ & $7.1 \pm 0.07$ & $7.0 \pm 0.15$ & $18.0 \pm 0.44$ \\
\hline \multicolumn{5}{|c|}{$\mathrm{CaCl}_{2}(\mathrm{mM})$} \\
\hline 0 & $7.0 \pm 0.02$ & $7.1 \pm 0.07$ & $0.3 \pm 0.03$ & $0.6 \pm 0.10$ \\
\hline 25 & $6.6 \pm 0.09$ & $6.4 \pm 0.08$ & $1.1 \pm 0.08$ & $6.5 \pm 0.69$ \\
\hline 50 & $6.6 \pm 0.03$ & $6.2 \pm 0.06$ & $4.9 \pm 0.09$ & $8.4 \pm 0.85$ \\
\hline 100 & $6.4 \pm 0.05$ & $6.2 \pm 0.04$ & $6.6 \pm 0.71$ & $14.9 \pm 0.79$ \\
\hline 150 & $6.4 \pm 0.04$ & $6.1 \pm 0.03$ & $9.7 \pm 0.26$ & $18.5 \pm 0.80$ \\
\hline 200 & $6.3 \pm 0.04$ & $6.2 \pm 0.06$ & $12.9 \pm 0.19$ & $20.6 \pm 0.30$ \\
\hline
\end{tabular}

3.2 Assessment of Chlorosis, Necrosis and Leaf Drying

Chlorosis was first visible in the plants treated with calcium chloride (Fig. 2). After 5 days of $\mathrm{CaCl}_{2}$ application at 100,150 and $200 \mathrm{mM}$, chlorosis symptoms were observed at about $30 \%$ of the leaves, and after 14 days all the leaves were clearly chlorotic. After 32 days, chlorosis was visible on the entire plants at all investigated calcium chloride concentrations.

The strongest chlorosis-inducing effect was observed for $150 \mathrm{mM} \mathrm{NaCl}$. The first symptoms for this concentration were visible on the fifth day (ca. 15\% of leaves), after 10, 12 and 14 days they could be spotted on about $80 \%$ of the leaves and after 24,27 and 32 days all the leaves were affected. The treatment with $50 \mathrm{mM} \mathrm{NaCl}$ induced about $30-50 \%$ leaf chlorosis after 10, 12, 14 and 20 days, but after 24, 27 and 32 days about $95 \%$ of the leaves were chlorotic. As mentioned previously, chlorosis was earlier visible on the plants treated with $\mathrm{CaCl}_{2}$ than on those treated with $\mathrm{NaCl}$.

Treatment with $\mathrm{CaCl}_{2}$ at 100,150 and $200 \mathrm{mM}$ induced clear leaf tissue necrosis after 10 days of the experiment (Fig. 3). First necroses for $25 \mathrm{mM} \mathrm{CaCl}_{2}$ were observed after 24 days. Leaf necrosis rate for the plants treated with this calcium chloride concentration was 40 and $75 \%$ after 27 and 32 days, respectively.

No necroses were observed in the plants treated with $25 \mathrm{mM} \mathrm{NaCl}$. Treatment with $50 \mathrm{mM} \mathrm{NaCl}$ rarely led to necrosis ( $10 \%$ of leaves). Two hundred millimolars $\mathrm{NaCl}$ caused clear necrosis of all leaf tissues after 20 days of the experiment.

The first symptoms of leaf drying were observed after 10 days of plant treatment with 100,150 or $200 \mathrm{mM}$ $\mathrm{CaCl}_{2}$ (Fig. 4). Complete drying was noticed after 20 days for $\mathrm{CaCl}_{2}$ at 100,150 or $200 \mathrm{mM}$. After 24, 27 and 32 days of treatment with $200 \mathrm{mM} \mathrm{NaCl}$, drying symptoms could be spotted on all leaves.

The images show the advancement of chlorosis, necrosis and leaf drying in $R$. rubiginosa plants treated with $100 \mathrm{mM} \mathrm{NaCl}$ (Fig. 1S) and $\mathrm{CaCl}_{2}$ (Fig. 2S). Calcium chloride was more toxic than $\mathrm{NaCl}$, as after 16 days most leaves exposed to $\mathrm{CaCl}_{2}$ were completely dry.

\subsection{Activity of Photosynthetic Apparatus}

Figure 5 presents alterations in maximum quantum efficiency of photosystem II $\left(F_{\mathrm{v}} / F_{\mathrm{m}}\right)$. A considerable decrease in $F_{\mathrm{v}} / F_{\mathrm{m}}$ was observed after 20 and 27 days in the 


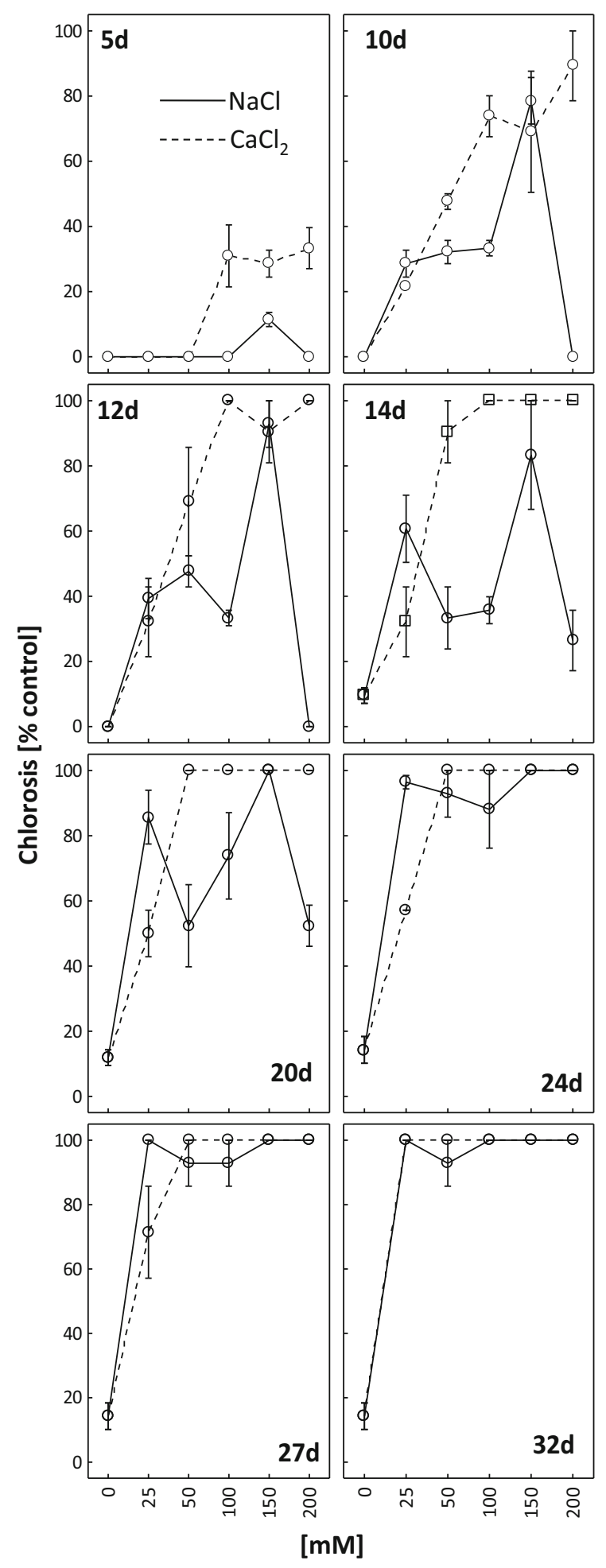

Fig. 2 Dynamics of chlorosis appearance and its intensity as percent of the control after 5, 10, 12, 14, 20, 24, 27 and 32 days of treating $R$. rubiginosa with $\mathrm{NaCl}$ (solid line) and $\mathrm{CaCl}_{2}$ (dashed line) solutions at various concentrations $(0,25,50,100,150$, $200 \mathrm{mM})$. Mean value $(n=3) \pm \mathrm{SE}$

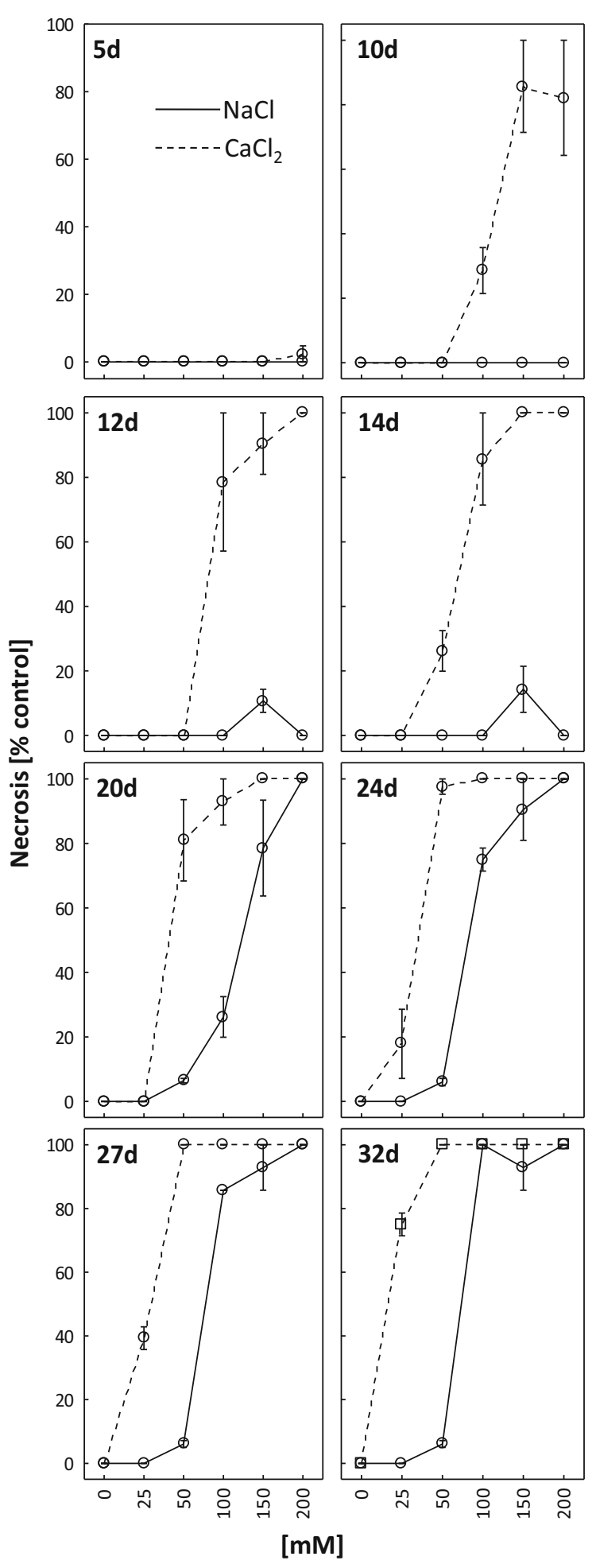

Fig. 3 Dynamics of necrosis appearance and its intensity as percent of the control after 5, 10, 12, 14, 20, 24, 27 and 32 days of treating $R$. rubiginosa with $\mathrm{NaCl}$ (solid line) and $\mathrm{CaCl}_{2}$ (dashed line) solutions at various concentrations $(0,25,50,100,150$, $200 \mathrm{mM})$. Mean value $(n=3) \pm \mathrm{SE}$ 


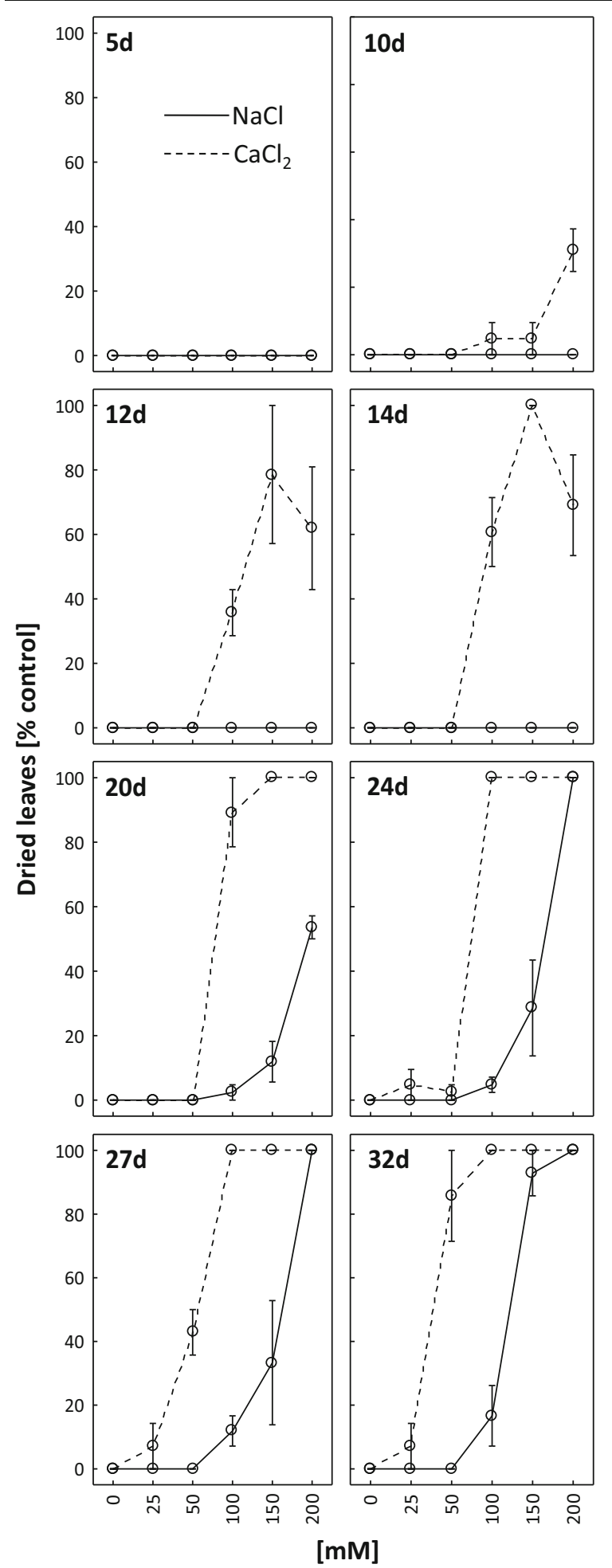

Fig. 4 Dynamics of leaf drying and its intensity as percent of the control after 5, 10,12,14,20,24, 27 and 32 days of treating R. rubiginosa with $\mathrm{NaCl}$ (solid line) and $\mathrm{CaCl}_{2}$ (dashed line) solutions at various concentrations $(0,25,50,100,150$, $200 \mathrm{mM})$. Mean value $(n=3) \pm \mathrm{SE}$ plants exposed to 150 and $200 \mathrm{mM}$ of sodium chloride. After 5, 10 and 14 days of treating the plants with $\mathrm{NaCl}$ solutions of different concentrations, maximum quantum yield of PSII was similar to the control $(0 \mathrm{mM})$.

Calcium chloride was much more detrimental to the photosynthetic apparatus activity. $\mathrm{CaCl}_{2}$ at 150 or $200 \mathrm{mM}$ reduced $F_{\mathrm{v}} / F_{\mathrm{m}}$ after as soon as 5 days (about $83 \%$ of control), and after 10 days the decrease was observed at $100 \mathrm{mM}$ ( $91 \%$ of control), $150 \mathrm{mM}$ (78\% of control) and $200 \mathrm{mM}$ (71\% of control) $\mathrm{CaCl}_{2}$. After 14 days, the ratio $F_{\mathrm{v}} / F_{\mathrm{m}}$ was completely reduced as a result of treatment with 150 and $200 \mathrm{mM} \mathrm{CaCl}_{2}$ and the same was observed at $100 \mathrm{mM} \mathrm{CaCl} l_{2}$ after 20 and 27 days.

Following 6 days of treatment with $25 \mathrm{mM} \mathrm{NaCl}$, the photosynthetic activity coefficient $\left(K_{\mathrm{phA}}\right)$ was clearly lower than in the control plants $(0 \mathrm{mM})$ (Fig. 6). Photosynthetic activity in the plants treated with 50 , 100 and $150 \mathrm{mM} \mathrm{NaCl}$ was similar to the control but it was higher than that at $\mathrm{NaCl}$ concentration of $200 \mathrm{mM}$. After 12 days, a decrease in photosynthetic activity was perceived for all the treatments, and the lowest $\mathrm{K}_{\mathrm{phA}}$ was reported for the plants treated with 150 and $200 \mathrm{mM} \mathrm{NaCl}$.

After 6 days of the experiment, photosynthetic activity of the plants exposed to $50,100,150$ or $200 \mathrm{mM}$ $\mathrm{CaCl}_{2}$ was lower than in the control (Fig. 6). However, slight increase in $K_{\text {phA }}$ was noticed for $25 \mathrm{mM}$ (118\% of control) $\mathrm{CaCl}_{2}$. $K_{\text {phA }}$ values were much lower than in the control after 12 days of exposure to 50 ( $47 \%$ of control), 100 (33\% of control), 150 (18\% of control) and $200 \mathrm{mM}$ ( $0 \%$ of control) $\mathrm{CaCl}_{2}$.

\subsection{Changes in Leaf Anatomy}

Twelve days of salt treatment resulted in significant changes in leaf anatomy (Fig. 7). Increasing concentration of any salt was accompanied by a decrease in leaf thickness. Considerable changes were visible for the plants treated with 100,150 and $200 \mathrm{mM}$ of $\mathrm{CaCl}_{2}$ and 150 and $200 \mathrm{mM}$ of $\mathrm{NaCl}$. High concentrations of both types of salt caused clear shrinkage of leaf epidermal cells. Moreover, elongation of palisade cells was observed for all $\mathrm{NaCl}$ and $\mathrm{CaCl}_{2}$ concentrations. Treatment with high concentrations of calcium chloride and sodium chloride (100-200 mM) caused visible deformation of the palisade cells and reduced their density. 


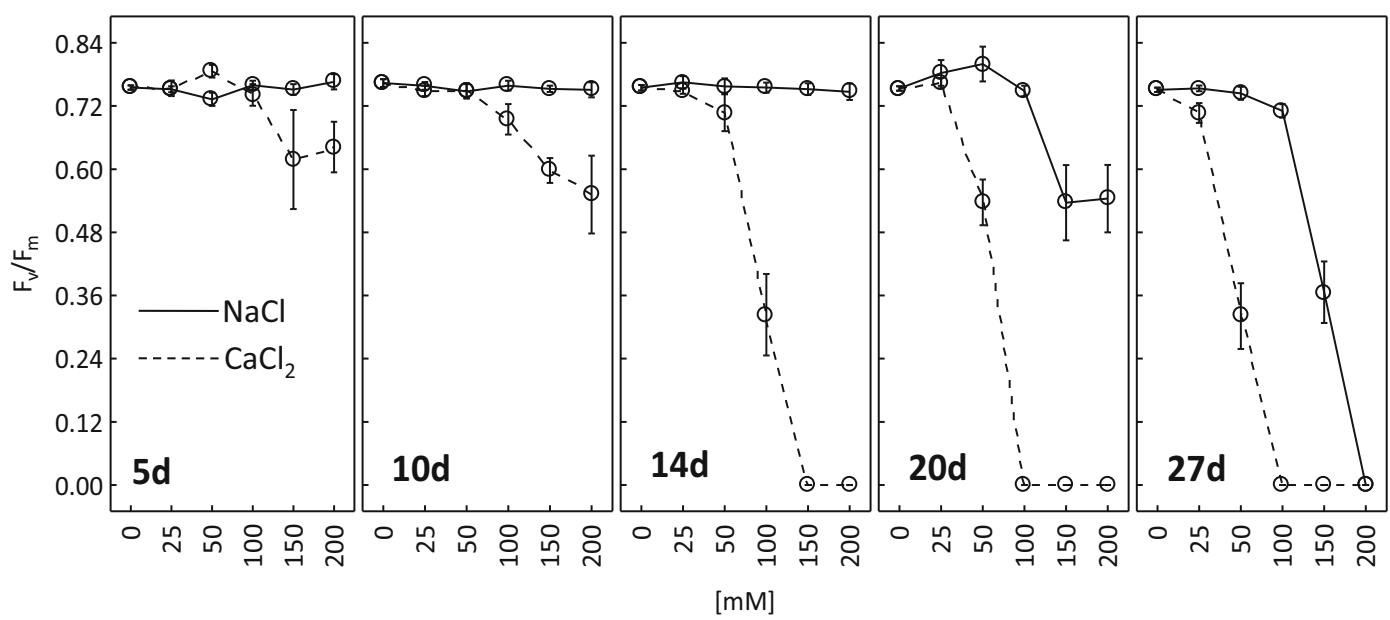

Fig. 5 Maximum photochemical efficiency of PSII $\left(F_{\mathrm{v}} / F_{\mathrm{m}}\right)$ after 5, 10, 14, 20, and 27 days of treating $R$. rubiginosa with $\mathrm{NaCl}$ (solid line) and $\mathrm{CaCl}_{2}$ (dashed line) solutions at various concentrations $(0,25,50,100,150,200 \mathrm{mM})$. Mean value $(n=5) \pm \mathrm{SE}$

\subsection{Leaf Water Content and Leaf Dry Weight}

Following 14 days of the experiment, a decrease in leaf water content was perceived in the plants exposed both to $\mathrm{NaCl}$ and $\mathrm{CaCl}_{2}$ (Fig. 8). LWC for 25, 50, 100, 150 and $200 \mathrm{mM} \mathrm{NaCl}$ was about $60 \%$ and about $20 \%$ less than control (about 85\%). In the plants exposed to calcium chloride, a gradual decrease in LWC was seen along with increasing salt concentration. The lowest leaf water content (about 30\%) was reported for $200 \mathrm{mM}$ of $\mathrm{CaCl}_{2}$.

All concentrations of $\mathrm{NaCl}$ stimulated leaf dry weight (Fig. 9). The same effect was perceived for the treatment with 25 and $50 \mathrm{mM}$ of $\mathrm{CaCl}_{2}$, and for the other calcium

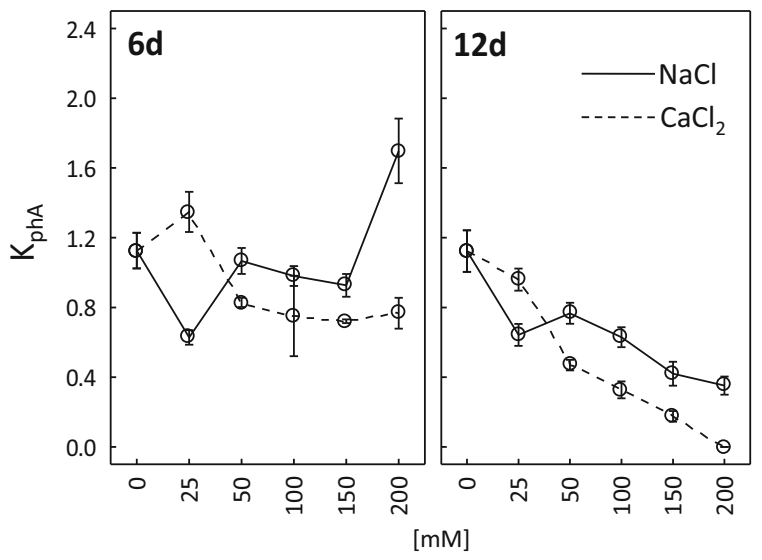

Fig. 6 Photosynthetic activity coefficient $\left(K_{\mathrm{phA}}\right)$ after 6 and 12 days of treating $R$. rubiginosa with $\mathrm{NaCl}$ (solid line) and $\mathrm{CaCl}_{2}$ (dashed line) solutions at various concentrations $(0,25,50,100$, $150,200 \mathrm{mM})$. Mean value $(n=5) \pm \mathrm{SE}$ chloride concentrations (100-200 mM), the dry weight was comparable to the control $(0 \mathrm{mM})$.

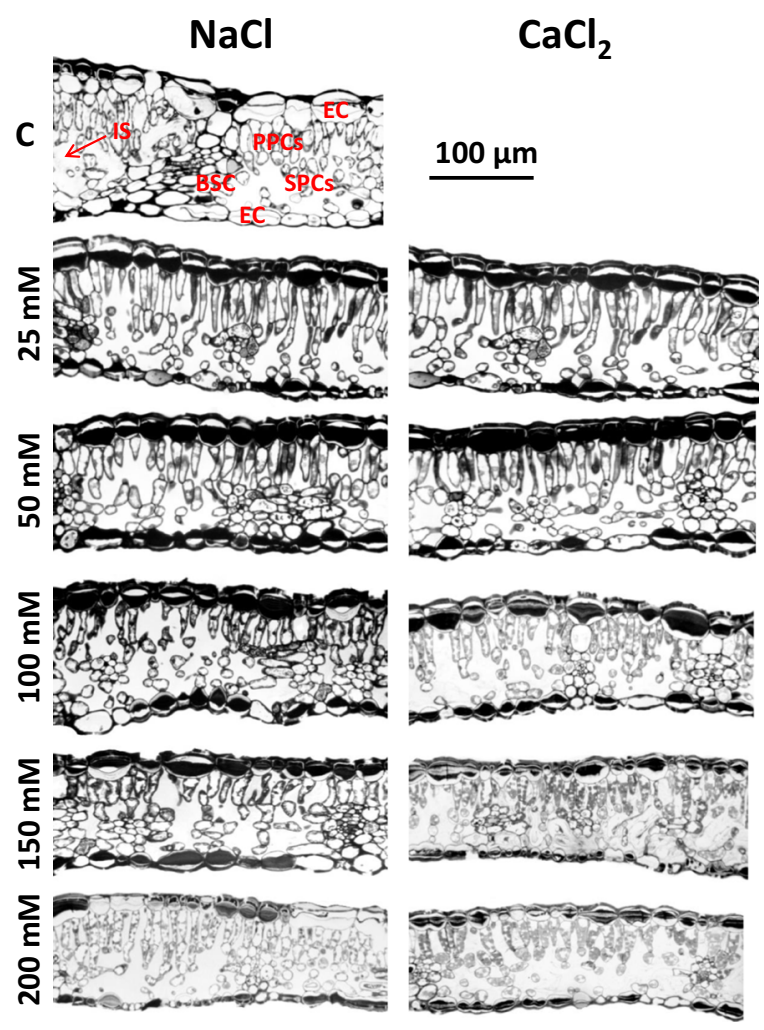

Fig. 7 Leaf cross-sections of R. rubiginosa after 12 days of treatment with $\mathrm{NaCl}$ and $\mathrm{CaCl}_{2}$ solutions at various concentrations $(0,25,50,100,150,200 \mathrm{mM}) . E C$ - epidermis cell, PPCs — palisade parenchyma cells, SPCs — spongy mesophyll cells, $B S C$ - bundle sheath cell, $I S$ - intercellular space 


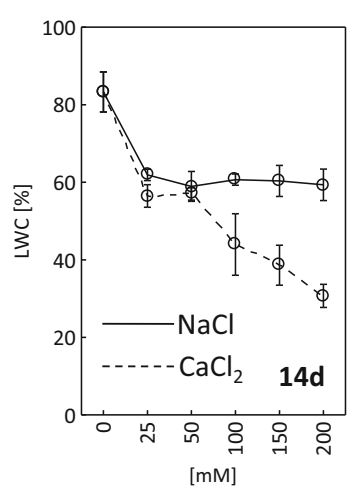

Fig. 8 Leaf water content (LWC) after 14 days of treating $R$. rubiginosa with $\mathrm{NaCl}$ (solid line) and $\mathrm{CaCl}_{2}$ (dashed line) solutions at various concentrations $(0,25,50,100,150$, $200 \mathrm{mM})$. Mean value $(n=7) \pm \mathrm{SE}$

\section{Discussion}

The study demonstrated greater accumulation of calcium chloride than sodium chloride in the soil (Table 1). High $\mathrm{CaCl}_{2}$ content caused limitations in water availability manifested as physiological drought (Yadav et al. 2011) that finally led to a decrease in leaf water content (Fig. 8) and fast leaf drying (Fig. 4, Fig. 2S). Sohan et al. (1999) and Romero-Aranda et al. (2001) demonstrated that increased salinity in the root zone resulted in lower leaf water content and led to the disruption of many important plant physiological processes. A similar decrease in leaf water content triggered by salt stress was observed in other studies (Ghoulam et al. 2002; Katerji et al. 1997; Kerepesi and Galiba 2000; Rivero et al. 2013; Turkan et al. 2013).

$R$. rubiginosa was more sensitive to the salinity induced by calcium chloride than by sodium chloride.

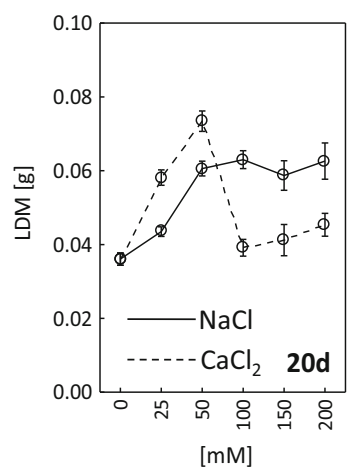

Fig. 9 Leaf dry weight (LDW) after 20 days of treating R. rubiginosa with $\mathrm{NaCl}$ (solid line) and $\mathrm{CaCl}_{2}$ (dashed line) solutions at various concentrations $(0,25,50,100,150$, $200 \mathrm{mM})$. Mean value $(n=7) \pm \mathrm{SE}$
Plant response to salinity was variable and depended on the salt concentration. In general, toxic effects were exacerbated by increasing salt concentration and exposure time. Our results have confirmed a well-known fact that chloride ions in the form of $\mathrm{CaCl}_{2}$ are more toxic to plants than other salts, such as $\mathrm{NaCl}$ or $\mathrm{KCl}$ (Cram 1973; Grattan and Grieve 1999; Kafkafi et al. 1992; Pessarakli 1991).

The effects of both types of salt on $R$. rubiginosa condition were manifested in the form of leaf chlorosis and necrosis (Figs. 2 and 3, Fig. 1S, Fig. 2S). Both changes were first perceived in the plants treated with calcium chloride, and this further confirmed greater toxicity of this salt towards $R$. rubiginosa. Chlorosis and necrosis triggered by substrate salinity were also described by other authors (Chan et al. 2011; Koffler et al. 2015; Paludan-Muller et al. 2002; Slabu et al. 2009). Wahome et al. (2001) reported higher tolerance of $R$. rubiginosa to $\mathrm{NaCl}$, as compared with Rosa chinensis that was manifested by more pronounced leaf necroses in the latter species. It should be pointed here that the treatment with $150 \mathrm{mM} \mathrm{NaCl}$ resulted in higher extent of leaf chlorosis compared to $200 \mathrm{mM}(5,10,12$, 14 and 20 days of treatment) (Fig. 2). We propose explanation that higher salt concentration may induce a more effective defence mechanisms than at lower salt concentration (Khan et al. 2000; Walia et al. 2007).

It is well-known that plants dynamically acclimate their photosynthetic system to environmental conditions (Repkova et al. 2009; Schurr et al. 2006). $\mathrm{CaCl}_{2}$ was more detrimental to the performance of the photosynthetic apparatus (Fig. 5) and photosynthetic activity (Fig. 6) than $\mathrm{NaCl}$. The studies of other authors also demonstrated a negative impact of salt stress on plant photosynthetic activity (Agastian et al. 2000; DionisioSese and Tobita 1998; Flexas et al. 2004; Kalaji et al. 2016; Koyro 2006; Tang et al. 2015). This may be due to, amongst others, lowered membrane permeability to $\mathrm{CO}_{2}$ (Iyengar and Reddy 1996), reduced nitrogen absorption from the soil (Fisarakis et al. 2001), stomatal closure (Parida et al. 2004) or decreased enzymatic activity (Iyengar and Reddy 1996). Salt stress was also reported to stimulate photosynthesis and plant biomass growth (Gu et al. 2016; Kurban et al. 1999; Parida et al. 2004; Redondo-Gómez et al. 2007). Our experiment demonstrated a stimulating effect of both low (25, $50 \mathrm{mM})$ and high $(100,150,200 \mathrm{mM})$ concentrations of $\mathrm{NaCl}$ and low concentrations of $\mathrm{CaCl}_{2}(25,50 \mathrm{mM})$ on dry weight of $R$. rubiginosa (Fig. 9). Khan et al. 
(2000) and Walia et al. (2007) claimed that the stimulating effect of salinity on plant dry weight might be due to increased concentrations of plant growth regulators (e.g. jasmonic acid) that may indirectly activate the genes (Rubisco, Rubisco activase) related to the photosynthetic activity.

Treatment with $\mathrm{CaCl}_{2}$ caused more visible deformation of palisade cells, reduced their density and considerably reduced leaf thickness (Fig. 7). However, it is advisable to confirm the changes in leaf anatomy of $R$. rubiginosa by precise measurements of epidermal thickness, mesophyll thickness, palisade cell length, palisade cell diameter, spongy cell diameter, stomatal density and intercellular spaces in future studies. Salt stress-induced changes in the anatomy of $R$. rubiginosa leaves were concurrent with the results of other studies (Garcia-Abellan et al. 2015; Longstreth and Nobel 1979; Parida et al. 2004; RomeroAranda et al. 2001; Yadav et al. 2011). These reports discussed the role of some leaf parameters and structures in the photosynthesis under salt stress.

Our study showed that $R$. rubiginosa has higher tolerance to salt stress induced by $\mathrm{NaCl}$ than by $\mathrm{CaCl}_{2}$. Visual effects of plant response to salt stress were variable and depended on the salt concentrations. High concentrations of $\mathrm{NaCl}$ and $\mathrm{CaCl}_{2}(100-200 \mathrm{mM})$ induced more intense chlorosis, necrosis and leaf drying than low concentrations of these salts $(25-50 \mathrm{mM})$. Summing up, we suggest that $R$. rubiginosa may be a natural indicator of urban soil salinity, particularly in the soils lining the communication routes where chemical agents to reduce road slippery are used.

Open Access This article is distributed under the terms of the Creative Commons Attribution 4.0 International License (http:// creativecommons.org/licenses/by/4.0/), which permits unrestricted use, distribution, and reproduction in any medium, provided you give appropriate credit to the original author(s) and the source, provide a link to the Creative Commons license, and indicate if changes were made.

\section{References}

Agastian, P., Kingsley, S., \& Vivekanandan, M. (2000). Effect of salinity on photosynthesis and biochemical characteristics in mulberry genotypes. Photosynthetica, 38, 287-290.

Bankaji, I., Caçador, I., \& Sleimi, N. (2016). Assessing of tolerance to metallic and saline stresses in the halophyte Suaeda fruticosa: the indicator role of antioxidative enzymes. Ecological Indicators, 64, 297-308.
Bowman, D. C., Devitt, D. A., \& Miller, W. W. (2006). The effect of moderate salinity on nitrate leaching from bermudagrass turf: a lysimeter study. Water, Air, and Soil Pollution, 175, 49-60.

Chan, Z. L., Grumet, R., \& Loescher, W. (2011). Global gene expression analysis of transgenic, mannitol producing, and salt-tolerant Arabidopsis thaliana indicates widespread changes in abiotic and biotic stress-related genes. Journal of Experimental Botany, 62, 4787-4803.

Cram, W. J. (1973). Internal factors regulating nitrate and chloride influx in plant cells. Journal of Experimental Botany, 24, 328-341.

Cunningham, M. A., Snyder, E., Yonkin, D., Ross, M., \& Elsen, T. (2008). Accumulation of deicing salts in soils in an urban environment. Urban Ecosystems, 11, 17-31.

Czerniawska-Kusza, I., Kusza, G., \& Duzynski, M. (2004). Effect of de-icing salts on urban soils and health status of roadside trees in the Opole region. Environmental Toxicology, 19, 296-301.

De Pietri, D. E. (1992). Alien shrubs in a national park: can they help in the recovery of natural degraded forest? Biological Conservation, 62, 127-130.

Dionisio-Sese, M. L., \& Tobita, S. (1998). Antioxidant responses of rice seedlings to salinity stress. Plant Science, 135, 1-9.

Di Tommaso, A. (2004). Germination behavior of common ragweed (Ambrosia artemisiifolia) populations across a range of salinities. Weed Science, 52, 1002-1009.

El-Haddad, E., \& Noaman, M. (2001). Leaching requirement and salinity threshold for the yield and agronomic characteristics of halophytes under salt stress. Journal of Arid Environments, 49, 865-874.

Fisarakis, I., Chartzoulakis, K., \& Stavrakas, D. (2001). Response of sultana vines ( $V$. vinifera L.) on six rootstocks to $\mathrm{NaCl}$ salinity exposure and recovery. Agricultural Water Management, 51, 13-27.

Flexas, J., Bota, J., Loreto, F., Cornic, G., \& Sharkey, T. D. (2004). Diffusive and metabolic limitations to photosynthesis under drought and salinity in $\mathrm{C}_{3}$ plants. Plant Biology, 6, 269-279.

Forssmann, W. G. (1969). A method for in vivo diffusion tracer studies combining perfusion fixation with intravenous tracer injection. Histochemie, 20, 277-286.

Garcia-Abellan, J. O., Fernandez-Garcia, N., Lopez-Berenguer, C., Egea, I., Flores, F. B., Angosto, T., Capel, J., Lozano, R., Pineda, B., \& Moreno, V. (2015). The tomato res mutant which accumulates JA in roots in non-stressed conditions restores cell structure alterations under salinity. Physiologia Plantarum, 155, 296-314.

Ghoulam, C., Foursy, A., \& Fares, K. (2002). Effects of salt stress on growth, inorganic ions and proline accumulation in relation to osmotic adjustment in five sugar beet cultivars. Environmental and Experimental Botany, 47, 39-50.

Grattan, S. R., \& Grieve, C. M. (1999). Salinity-mineral nutrient relations in horticultural crops. Scientia Horticulturae, 78, 127-157.

Gu, M. F., Li, N., Long, X. H., Brestic, M., Shao, H. B., Li, J., \& Mbarki, S. (2016). Accumulation capacity of ions in cabbage (Brassica oleracea L.) supplied with sea water. Plant, Soil and Environment, 62, 314-320.

Han, R. M., Lefèvre, I., Ruan, C. J., Beukelaers, N., Qin, P., \& Lutts, S. (2012). Effects of salinity on the response of the 
wetland halophyte Kosteletzkya virginica (L.) Presl. to copper toxicity. Water, Air, and Soil Pollution, 223, 1137-1150.

Iyengar, E. R. R., \& Reddy, M. P. (1996). Photosynthesis in highly salt-tolerant plants. In M. Pessaraki (Ed.), Handbook of photosynthesis (pp. 897-909). New York: Marcel Dekker.

Kafkafi, U., Siddiqi, M. Y., Ritchie, R. J., Glass, A. D. M., \& Ruth, T. L. (1992). Reduction of nitrate $\left({ }^{13} \mathrm{NO}_{3}\right)$ influx and nitrogen $\left({ }^{13} \mathrm{~N}\right)$ translocation by tomato and melon varieties after short exposure to calcium and potassium chloride salts. Journal of Plant Nutrition, 15, 959-975.

Kalaji, H. M., Jajoo, A., Oukarroum, A., Brestic, M., Zivcak, M., Samborska, I. A., Cetner, M. D., Łukasik, I., Goltsev, V., \& Ladle, R. J. (2016). Chlorophyll $a$ fluorescence as a tool to monitor physiological status of plants under abiotic stress conditions. Acta Physiologiae Plantarum, 38, 102.

Katerji, N., van Hoorn, J. W., Hamdy, A., Mastrorilli, M., \& Moukarzel, E. (1997). Osmotic adjustment of sugar beets in response to soil salinity and its influence on stomatal conductance, growth and yield. Agricultural Water Management, 34, 57-69.

Kerepesi, I., \& Galiba, G. (2000). Osmotic and stress-induced alteration in soluble carbohydrate content in wheat seedlings. Crop Science, 4, 482-487.

Khan, M. A., Ungar, I. A., \& Showalter, A. M. (2000). The effect of salinity on the growth, water status, and ion content of a leaf succulent perennial halophyte, Suaeda fruticosa (L.) Forssk. Journal of Arid Environments, 45, 73-84.

Kissell, R. M., Wilson, J. B., Bannister, P., \& Mark, A. F. (1987). Water relations of some native and exotic shrubs of New Zealand. New Phytologist, 107, 29-37.

Koffler, B. E., Luschin-Ebengreuth, N., \& Zechmann, B. (2015). Compartment specific changes of the antioxidative status in Arabidopsis thaliana during salt stress. Journal of Plant Biology, 58, 8-16.

Koyro, H. W. (2006). Effect of salinity on growth, photosynthesis, water relations and solute composition of the potential cash crop halophyte Plantago coronopus (L.). Environmental and Experimental Botany, 56, 136-146.

Kurban, H., Saneoka, H., Nehira, K., Adilla, R., Premachandra, G. S., \& Fujita, K. (1999). Effect of salinity on growth, photosynthesis and mineral composition in leguminous plant Alhagi pseudoalhagi (Bieb.). Soil Science and Plant Nutrition, 45, 851-862.

Longstreth, D. J., \& Nobel, P. S. (1979). Salinity effects on leaf anatomy. Consequences for photosynthesis. Plant Physiology, 63, 700-703.

Luft, J. H. (1961). Improvements in epoxy resin embedding methods. The Journal of Biophysical and Biochemical Cytology, 9, 409-414.

Monder, M. J. (2004a). Observations of frost resistance of cover roses in the roses collection in the Botanical Garden of Polish Academy of the Sciences in Warsaw after frosty winter 2002/2003. Bulletin of the Botanical Gardens, Museums and Collections, 13, 187-197.

Monder, M. J. (2004b). Observations of overwintering of historical roses in roses collection of Botanical Garden of Polish Academy of Sciences in Warsaw after frosty winter 2002/2003. Bulletin of the Botanical Gardens, Museums and Collections, 13, 197-207.

Monder, M. J. (2012). Evaluation of growth and flowering of cultivars derived from the rugosa (Rosa rugosa Thunb.) growing in the national collection of rose cultivars in the Polish Academy of Sciences Botanical Garden in Powsin. Part II. The modern cultivars. Acta Agrobotanica, 65, 117124.

Nandy, P., Das, S., Ghose, M., \& Spooner-Hart, R. (2007). Effects of salinity on photosynthesis, leaf anatomy, ion accumulation and photosynthetic nitro gen use efficiency in five Indian mangroves. Wetlands Ecology and Management, 15, 347357.

Novotny, E. V., \& Stefan, H. G. (2010). Projections of chloride concentrations in urban lakes receiving road de-icing salt. Water, Air, and Soil Pollution, 211, 261-271.

Paludan-Muller, G., Saxe, H., Pedersen, L. B., \& Randrup, T. B. (2002). Differences in salt sensitivity of four deciduous tree species to soil or airborne salt. Physiologia Plantarum, 114, 223-230.

Parida, A. K., Das, A. B., \& Mittra, B. (2004). Effects of salt on growth, ion accumulation, photosynthesis and leaf anatomy of the mangrove, Bruguiera parviflora. Trees-Structure and Function, 18, 167-174.

Pessarakli, M. (1991). Dry matter yield, nitrogen-15 absorption, and water uptake by green bean under sodium chloride stress. Crop Science, 31, 1633-1640.

Pouyat, R. V., McDonnell, M. J., \& Pickett, S. T. A. (1995). Soil characteristics of oak stands along an urban-rural land-use gradient. Journal of Environmental Quality, 24, 516-526.

Redondo-Gómez, S., Mateos-Naranjo, E., Davy, A. J., FernandezMunoz, F., Castellanos, E. M., Luque, T., \& Figueroa, M. E. (2007). Growth and photosynthetic responses to salinity of the salt-marsh shrub Atriplex portulacoides. Annals of Botany, 100, 555-563.

Redondo-Gómez, S., Mateos-Naranjo, E., \& Figueroa, M. E. (2009). Synergic effect of salinity and light-chilling on photosystem II photochemistry of the halophyte, Sarcocornia fruticosa. Journal of Arid Environments, 73, 586-589.

Repkova, J., Brestic, M., \& Olsovska, K. (2009). Leaf growth under temperature and light control. Plant, Soil and Environment, 55, 551-557.

Richardson, K. C., Jawett, L., \& Finke, E. H. (1960). Embedding in epoxy resins for ultrathin sectioning in electron microscopy. Stain Technology, 35, 313-323.

Ritz, C. M., Maier, W. F. A., Oberwinkler, F., \& Wissemann, V. (2005). Different evolutionary histories of two Phragmidium species infecting the same dog rose hosts. Mycological Research, 109, 603-609.

Rivero, R. M., Mestre, T. C., Mittler, R. O. N., Rubio, F., GarciaSanchez, F., \& Martinez, V. (2013). The combined effect of salinity and heat reveals a specific physiological, biochemical and molecular response in tomato plants. Plant, Cell and Environment, 37, 1059-1073.

Romero-Aranda, R., Soria, T., \& Cuartero, S. (2001). Tomato plant-water uptake and plant-water relationships under saline growth conditions. Plant Science, 160, 265-272.

Sage, D. J. M., Norton, D. A., \& Espie, P. R. (2009). Effect of grazing exclusion on the woody weed Rosa rubiginosa in high country short tussock grasslands. New Zealand Journal of Agricultural Research, 52, 123-128.

Sheley, R. L., Svejcar, T. J., \& Maxwell, B. D. (1996). A theoretical framework for developing successional weed management strategies on rangeland. Weed Technology, 10, 766773. 
Schurr, U., Walter, A., \& Rascher, U. (2006). Functional dynamics of plant growth and photosynthesis - from steady-state to dynamics - from homogeneity to heterogeneity. Plant, Cell \& Environment, 29, 340-352.

Slabu, C., Zörb, C., Steffens, D., \& Schubert, S. (2009). Is salt stress of faba bean (Vicia faba) caused by $\mathrm{Na}^{+}$or $\mathrm{Cl}^{-}$toxicity? Journal of Plant Nutrition and Soil Science, 172, 644-650.

Sohan, D., Jason, R., \& Zajcek, J. (1999). Plant-water relations of $\mathrm{NaCl}$ and calcium-treated sunflower plants. Environmental and Experimental Botany, 42, 105-111.

Svriz, M., Damascos, M. A., Zimmermann, H., \& Hensen, I. (2013). The exotic shrub Rosa rubiginosa as a nurse plant. Implications for the restoration of disturbed temperate forests in Patagonia, Argentina. Forest Ecology and Management, 289, 234-242.

Tang, X. L., Mu, X. M., Shao, H. B., Wang, H. Y., \& Brestic, M. (2015). Global plant-responding mechanisms to salt stress: physiological and molecular levels and implications in biotechnology. Critical Reviews in Biotechnology, 35, 425-437.

Turkan, I., Demiral, T., \& Sekmen, A. H. (2013). The regulation of antioxidant enzymes in two Plantago species differing in salinity tolerance under combination of waterlogging and salinity. Functional Plant Biology, 40, 484-493.

van Kooten, O., \& Snel, J. F. H. (1990). The use of fluorescence nomenclature in plant stress physiology. Photosynthesis Research, 25, 147-150.

Wahome, P. K., Jesch, H. H., \& Grittner, I. (2001). Mechanisms of salt stress tolerance in two rose rootstocks: Rosa chinensis 'Major' and R. rubiginosa. Scientia Horticulturae, 87, 207216.

Walia, H., Wilson, C., Condamine, P., Liu, X., \& Ismail, A. M. (2007). Largescale expression profiling and physiological characterization of jasmonic acid-mediated adaptation of barley to salinity stress. Plant, Cell and Environment, 30, 410421.

Williams, C. E. (1997). Potential valuable ecological functions on non-indigenous plants. In J. O. Luken \& J. W. Thieret (Eds.), Assessment and management of plant invasions (pp. 26-34). New York: Springer.

Yadav, S., Irfan, M., Ahmad, A., \& Hayat, S. (2011). Causes of salinity and plant manifestations to salt stress: a review. Journal of Environmental Biology, 32, 667-685.

Zeng, S. L., Zhang, T. T., Gao, Y., Li, B., Fang, C. M., Flory, S. L., \& Zhao, B. (2012). Road effects on vegetation composition in a saline environment. Journal of Plant Ecology, 5, 206218.

Zhang, D., Tong, J., He, X., Xu, Z., Xu, L., Wei, P., Huang, Y., Brestic, M., Ma, H., \& Shao, H. (2016). A novel soybean intrinsic protein gene, GmTIP2;3, involved in responding to osmotic stress. Frontiers in Plant Science, 6, 1237.

Zhang, S., Song, J., Wang, H., \& Feng, G. (2010). Effect of salinity on seed germination, ion content and photosynthesis of cotyledons in halophytes or xerophyte growing in Central Asia. Journal of Plant Ecology, 3, 259-267.

Zimmermann, H., Ritz, C., Hirsch, H., Renison, D., Wesche, K., \& Hensen, I. (2010). Highly reduced genetic diversity of Rosa rubiginosa L. populations in the invasive range. International Journal of Plant Sciences, 171, 435-446.

Zimmermann, H., Wehrden, H., Damascos, M., Bran, D., Welk, E., Renison, D., \& Hensen, I. (2011). Habitat invasion risk assessment based on Landsat 5 data, exemplified by the shrub Rosa rubiginosa in southern Argentina. Austral Ecology, 36, 870-880. 